\title{
Religious experience in the current theological discussion and in the church pew
}

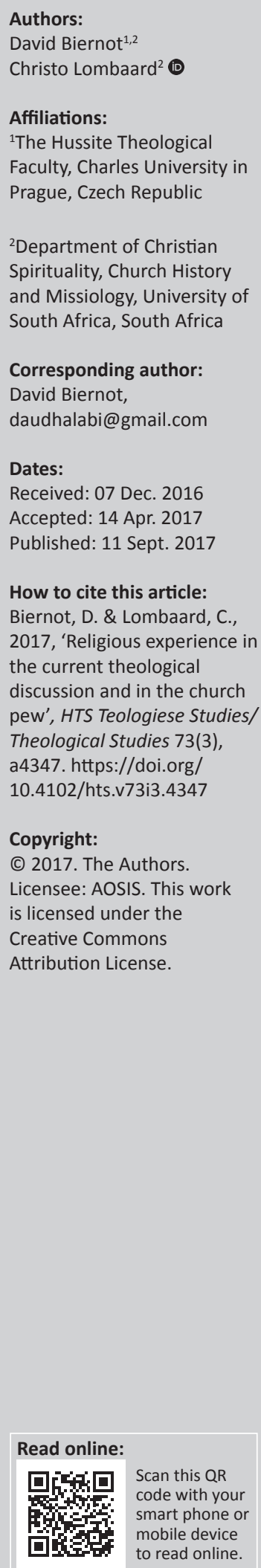

Taking a new look at the language of 'religious experience', the authors in this contribution take into review this aspect in the current theological discussion, and in the church pew, asking the question: Does George Lindbeck's criticism of the experiential-expressive model of religion still have something to say to us? Firstly, Lindbeck is reviewed and recouped. Then, religious experience and its commodification are discussed, at the hand also of the heritage from Schleiermacher onwards on experience. Taking a position within the post-modern, relativist, critical realist and pragmatist possibilities, a community-embedded sense of truth is concluded to without sacrificing the possibility of universalising claims. Is it possible, though, within the cultural reflex towards psychologised faith to retain a historically oriented depth?

\section{Back to Lindbeck}

'Religious experience' ranks amongst the basic terminology that theologians and lay believers have over the past two centuries often used to refer to matters of faith. In this, the foundational works of William James (The Varieties of Religious Experience, 1902) and Rudolph Otto (Das Heilige, 1917 and The Idea of the Holy, 1923) played foundational roles. 'Religious experience' has since then become a pervasive element of religious language, in its various genres and on various practices. Yet, is indeed the meaning of this reference entirely clear?

This contribution puts into focus some recent trans-disciplinary theological discussions on religious experience; however, the scope here is more applied too, to reflect on current Christian practice, namely on the place of experience within its precincts. In this, the Reformation commemorated by the present volume is honoured: Amongst the contributions of the Reformation counts, the 'democratisation' of theological discourse, namely that which also touches the heart of the individual believers and of them as a collective - the church. Half a millennium after the Reformation, that contribution remains one of the most productive.

It is however, in particular, in this 'democratisation' that some worrying tendencies of continued inflation or perhaps hypertrophy can be discerned, in the form of a commodification of religious experience in the church ${ }^{1}$ pews. It seems at the moment that no significant lesson has been learned from the criticism levelled against the experiential-expressive model of religion some three decades ago by George Lindbeck, in his Nature of Doctrine: Religion and Theology in a Postliberal Age (1984). In the intervening period, however, Lindbeck's position has had to sustain criticism, at times to the point of denigration, as some have pointed out that Lindbeck's analysis of the relation between experience and language was out of date already at the time of writing: The inadequacy of a romantic-idealist understanding of language and referentiality had been recognised at least since the early 1970s. In the eyes of his critics, Lindbeck's category of experiential expressivism amounted to an oversimplified scheme - a 'straw-man' easily knocked down (DeHart 2006:164-165). The authors of this article are aware of the above criticism; nevertheless, even when accepting the objections to Lindbeck's shortcomings, his work The Nature of Doctrine (1984) managed, in its 'oversimplified' division of theological thought into three models (vide infra), to attain two matters:

1. to provide a valuable tool for at least two generations of theologians to orient themselves on the past development of Christian theology, and

2. to offer solutions to some current burning issues, above all those related to the ecumenical and pluralistic nature of the religious situation in the 1980s, and hence also in the situation of our time.

This applies especially for our purposes here to his critical observations on the overly confident emphasis placed on religious experience in theology and church life since the period of Romanticism.

1.Here, with "church" is not meant any specific denomination, but the more general indication of Christian observants. 
Much has been written about religious experience during the past two centuries, and theologians and religionists still continue to study this subject (see e.g. Alston 1991; Proudfoot 1985; Steinbock 2007; Taves 2009; Twiss 1992). Amongst the most respected of these, enjoying a sort of 'canonical' status, is The Varieties of Religious Experience by William James (1902) referred to above, in which the understanding of religion in the proper sense fits precisely an experiential-expressive model (Lindbeck 1984:32-33). As is well known, James divided religion into two main categories: the institutional, which included church, theology and worship, and then the personal, experiential perspective. It is the latter to which his lectures are dedicated (in the language of that time): '... the feelings, acts, and experiences of individual men in their solitude, so far as they apprehend themselves to stand in relation to whatever they may consider the divine' (James 2002 [1902]:38).

Despite the considerable number of studies addressing religious experience as a problem per se, we theologians often employ this notion without giving it a second thought, unreflectively assimilating 'religious experience' into our nomenclature. Yet, upon closer inspection, religious experience appears to raise a number of questions, amongst which the most prominent are those of an epistemological nature. It would be short-sighted not to see that the standoff between realistic epistemologies - above all critical realism, which arose during the past two decades, and nonrealism, which grew out of the linguistic turn in philosophy - has not spilled over from philosophy to theology (McGrath 2002). Moreover, theologians ought to give critical thought to the growing and far-reaching emphasis, the commonly encountered pressure, either to have or to develop some kind of religious experience, as has risen to prominence especially amongst evangelicals. This phenomenon onesidedly applied and critically unexamined, would have a detrimental effect on the profundity and richness of Christian spirituality in all its breadth.

\section{Religious experience and foundationalism}

According to Lindbeck, late 20th century theological theories of religion could be broken down into three models (Lindbeck 1984:16). The first of these emphasises the cognitive aspects of religion, bringing to the fore the ways in which ecclesiastical doctrines are supposed to operate as informative propositions or truth statements about objective realities. This type of theory characterises traditionally orthodox understandings that attribute to religious statements a function of ontological correspondence, or an 'isomorphism' of the structure of knowing and the structure of the known (Lindbeck 1984:47). Propositionalism, as this model may be called, tends to bring out aspects such as the inerrant doctrinal core of Christianity. Each proposition or act of judgement is thought to correspond or not correspond to eternal reality. In the modern history of Christian spirituality, pure propositionalism is encountered rarely or has evolved into its stricter form, fundamentalism (Lindbeck 1984:24).
The second model reflects what Lindbeck calls an 'experiential-expressive dimension' of religion, in which doctrines function as non-informative and non-discursive symbols of inner feelings, attitudes or existential orientation (Lindbeck 1984:16). Lindbeck, however, makes a case for a third model, a cultural-linguistic model of religion, because he finds the first type unsatisfying in the age of pluralism and ecumenical dialogue, and the second for reasons that are specified below. It is noteworthy, though, that propositionalism and the experiential-expressive type of spirituality appear to have a common denominator, foundationalism. Richard Rorty defines such foundationalism as an epistemological view that is adopted by those who suspend judgement on the realist's claim that reality has an intrinsic nature. Every belief held by a foundationalist must occupy a place in a natural, transcultural and trans-historical order of reasons - an order that leads the inquirer back to one or another sort of evidence (Rorty 2005:33). This ultimate, foundational source of evidence can be of various kinds: it may range from clear and distinct ideas to a canonised text, tradition and - finally - also to experience. The Australian theologian Wildman, noted for his extensive research on religious and spiritual experiences, points out how dear religious experience has become for a wide range of contemporary religious groups, a hinge on which swings the very meaning and purpose of one's life (Wildman 2011):

Let us consider a third motivation that people bring to the study of RSEs. ${ }^{2}$ I shall relate three personal experiences and then ask what they have in common. First, several of my friends, disciples of the Dalai Lama, want me to practice meditation. They are confident that my experiences while meditating will demonstrate to me the transitory and ephemeral nature of reality, thereby freeing me from my attachment to the big and small concerns of life, and sparking within me a powerful form of compassion for all living creatures. The experience will change my life and bring meaning and purpose that I never imagined possible. Second, several of my New Age friends urge me to try any number of ways of connecting to the flowing energies just beneath the surface of ordinary life. Their Daoist-like worldview predicts that I will have powerful experiences of feeling centered, energized, and healthy to an unprecedented degree. The experience will change my life and bring meaning and purpose that I never imagined possible. Third, several of my evangelical Christians friends want me to experience the presence of the risen Jesus Christ as a living personal being, constantly communicating with me and being my companion in the trials and joys of this life, and my guide to the life beyond. All I have to do is to confess my sins, welcome Jesus into my life as my Lord and Savior, and love him and follow him with all my heart and soul and mind and strength. The experience will change my life and bring meaning and purpose that I never imagined possible.

What do these experiences have in common? Well, obviously, a number of people are trying to convert me to something, and evidently I come across as the sort of person who could profit from a conversion experience. But I want to draw your attention to something else, namely, the role that RSEs play in these conversion efforts. I am asked in the first instance not to be a Buddhist or a New Ager or a supernaturalist evangelical Christian, but rather to undergo an experience that will speak for 2.RSE, Religious and spiritual experiences. 
itself. My friends are confident in their beliefs because the RSEs they have had feel so compelling to them, and seem to confirm their beliefs so strongly. They believe that if I have these same experiences, then I will also believe as they do. (pp. 8-9)

Wildman's observations, gained during his research, are instructive in showing how strongly foundationalist the character of experience-centred spiritualities are; this, despite experientiality in Spirituality Studies usually being closely related with inherently non-foundationalist post-modernism (cf. e.g. Kourie 2006:75-94). Despite the fact that the three examples in the quote above are related to quite different and varied religious groupings, there is a common denominator to all of them: the conviction of a compelling, meaningforging and transformative momentum of religious experience, which would bring the person into immediate contact with an ultimate reality - whatever the latter may mean. This compelling character of religious experience is assumed inherently to speak for itself, self-efficaciously. Religious experiences thus turn out to be self-explanatory; their truth non-refutable. This renders those who undergo these experiences seemingly oblivious to the cultural and personal assumptions preconditioning those experiences (Wildman 2011:12).

Nevertheless, as pointed out by Rorty (2004:86-88), the inherently forceful and compelling character of a religious experience caused even William James in his Varieties of Religious Experience (1902) at times to digress from his pragmatist approach. There are passages in which James seems to be indifferent to the question of whether religious experiences do provide empirical evidence of a supernatural cause, as his attention is then drawn solely to the question of how human beings pass through life without been smitten by depression. In such moments, James would ascribe the salutary impact of religious experiences to human subconsciousness. Yet, on other occasions, James would postulate that these experiences provide us with as clear evidence for the existence of 'a wider self from which saving experiences come' - a self-conscious non-human life - as there is evidence for the existence of penguins.

\section{A helpful excursion to Schleiermacher}

Although the above examples by Wildman reflect the diverse religious situation at the beginning of the 21st century, one is capable of discerning deeper strains in the mentioned groups' rhetorics that are traceable to the late 18th century to be more exact, to the religious philosophy of Friedrich Schleiermacher. It should be noted that the very notion of 'religious experience' is a relatively recent concept, coined not earlier than 200 years ago, and its provenance has always been more or less confined to the West (Proudfoot 1985:xii-xv). Although it cannot be denied that the experiential aspect has always been present within Christian and other spiritualities, it is also clear that modern research has a proclivity to overemphasise the significance of this phenomenon in pre-modern periods. For instance, when
Jürgen Moltmann addresses the subject of mystical theology, he launches into it in the following way: 'Mystical theology aims at being a wisdom drawn from experience ... It is mystical only because it tries to put mystical experience into words' (Moltmann 1992:198). However, Bernard McGinn (2001:20-21) and others ${ }^{3}$ warn of arriving at such hasty conclusions: many Christian mystics of the pre-modern era did not relate to special experiences, or they downplayed their significance. Mystics like Meister Eckhart would take recourse to a dialectics full of paradoxes precisely to make clear that God cannot be captured experientially. Eckhart occasionally describes a disrupting sensation the soul experiences while hovering over the abyss of its own emptiness, but as Turner (1995:177) argues, these descriptions are perfunctory, colourless and conventional. Meister Eckhart also condemned the efforts of those striving to reach visions of God as the manifestation of 'merchant mentality' - or what we would in modern parlance dub the commodification of religious experience.

It was with Schleiermacher that the idea of religious experience started to rise to such a towering prominence. The centrality it had assumed in the theological thought of the liberal period can best be understood against the philosophical and theological background of the outgoing 18th century. The traditional appeals to metaphysical argument justifying religious belief had been undermined by Immanuel Kant, whose criticism effectively crushed the appeal to metaphysics and ruled out the applicability of empirical evidence on the existence of God (Proudfoot 1985:2-3). The development of historical criticism in Bible exegesis also significantly reduced the possibility to appeal to a Scriptural authority. Henceforth, religion would be thrown back onto the category of experience, endowed with an intrinsic, underivable religious quality that would preclude the requirement to be justified by metaphysical argument, or from design argument, or from moral life. Religious experience was to be elevated beyond Kant's epistemological presupposition that our experience is structured by the categories of thought to be applied to all aspects of life.

In this way, religion regained some footing and hence could not be simply assimilated by either scientific or moral paradigms. Influenced, amongst other sources, by the Moravian Brethren, Schleiermacher scrambled to present piety, understood as an inner emotional and affective movement, as a non-derivative a priori, directly referring to something other than the self and the world (Proudfoot 1987:10-15). Drawing on the above observations by Wildman, religious experience is thought to speak for itself. If in this line of thinking religious experience is at all made dependent on any set of doctrines and beliefs, then these are seen as serving solely as an expression of the inner state of

3.McGinn agrees on this with his predecessors in research on Meister Eckhart, such as Kurt Flasch for whom Eckhart was a philosopher and not a mystic. McGinn (2001) puts his view across in the following way: To be sure, the term mystic is a modern puts his view across in the following way: To be sure, the term mystic is a modern creation ... most of contemporary scholars, whatever their disagreements, scarcely think of mysticism in the manner Flasch and his colleagues conceive of it, that is, as something private, purely emotional, irrational, and always based on claims of personal ecstatic experience. If that is the true definition of mysticism, Eckhart is no a mystic, but neither is John of the Cross or a host of the other figures traditionally identified as mystics in the history of the church (pp. 21-22). 
consciousness. Religious language, in this case, is degraded to a sort of verbal extension of the natural, spontaneous and involuntary manifestation of inner mental states.

Schleiermacher's approach continued substantially to inform the following generations of theologians and Religious Studies scholars of the liberal period. For example, James (2002 [1902]:433) was convinced that 'feeling is the deeper source of religion' and that philosophical and theological formulations are secondary and 'presuppose immediate experience as their subjectmatter'. Paul Tillich on his part embraced in addition to Schleiermacher the Augustinian teaching of an implanted knowledge of God (cognitio dei insita) that became essential for his (Tillich's) later writings. In his dissertation entitled Mysticism and Consciousness of Guilt in Schelling's Philosophical Development, Tillich (1974 [1912]) sets the 'feeling of unity with God', who is the principle of identity of the absolute and individual spirit, against the experience of the contradiction between the holy Lord and the sinful creature. The truth of religion consists in the certitude of God as the unconditional that is contained in the certitude of the self and provides the latter with grounding. The immediate experience of one's own subjectivity also counts as the experience of being held by something that is not part of the world. In this way, God is conceived of as the most profound experiential reality accessible to every human being (Manning 2009:41-42).

\section{Commodification of religious experience}

The concern in this contribution is not only the foundationalism, indicated above, embraced by ever increasing numbers of believers, which then elevates religious experience to a favoured and self-explanatory position, as if forging immediate contact with an ultimate reality. The currently dominant understanding of religious experience deserves closer scrutiny also for another reason, touched on earlier: the increasing importance religious experience has taken on in the commodification of religion. Religious experience has widely turned into a commodity to be consumed and savoured here and now. Quite familiar by now are the clichés deriding consumerism, setting it apart from 'genuine' evangelical values. Yet, it becomes increasingly clear that both matters, consumerism and religious experience, show remarkable overlapping tendencies, often becoming entangled. In Consuming Religion: Christian Faith and Practice in a Consumer Culture (2003), Vincent Miller argues that the shape and texture that the consumer culture cultivates are profoundly similar to Christian forms of desire and are hence capable of side-tracking Christianity in subtle but profound ways. The fact that modern capitalism finds in the famous analysis by Max Weber its roots in early Calvinism (cf. Otto 2005a; 2005b), renders such a confluence as fully in character. The conflict between Christianity and consumer culture thus cannot be described as an out and out clash or a head-on collision (Miller 2003:107-108).
Consuming society is tantamount to a 'desiring society'. Advanced capitalist society has developed sophisticated systems for forming and inciting desire (with the advertising and mass media industries often taking the brunt of criticism in this respect). This concern on enhancing desire is something that late capitalism shares with Christian spirituality, which is not necessarily bound to enhancing desire but rather wants to cultivate it - from germination to growth and development. Modern marketing and advertising form consumer desire in two complementary ways: seduction and misdirection. Seduction spurs consumption by prolonging desire, channelling its inevitable disappointments into further desires. Misdirection leads consumers to engage in consumption (the tongue-in-cheek expression 'retail therapy' illustrates this well enough) in order to meet their needs for identity and belonging. Finally, both forces combine to produce a fragmented form of desire that can be endlessly multiplied. This leads us also to deriving satisfaction in enjoying unfulfilled desire. When watching a shopping channel, we employ our imagination to consider what we would look like in this shirt or how that electronic gadget would make our home more cosy and comfortable (Miller 2003:122-125). Desiring therefore turns out to be pleasurable in itself, without the necessity of making a purchase. We remain in a state of constant arousal and deferred fulfilment. Miller (2003) compares this to mysticism refusing to connect satisfaction with mundane things:

The most pressing challenge of consumer desire, however, is not its difference from, but its profound similarity to, the form of the mystical ascent. Both share the same axiom, that particular objects cannot satisfy the depths of human longing. The mystical ascent tradition aimed to focus this dissatisfaction by generalizing it to entire classes of objects: material goods, other humans, intellectual concepts, and the like. Consumer seduction channels this fact of human nature in another direction: the endless seeking of fulfilments in more objects. The subject's desire is disseminated horizontally across an endless range of objects of the same class. The constant arousal of new desire short-circuits the lessons that could be learned from the disappointments with particular acts of consumption. Thus, just as it has found a way around Freud's pessimism concerning the possibility of maintaining happiness, it has also found a way to mitigate the spiritual reckoning that Christianity has long assumed was inevitable for the hedonist. We never tire of our earthly pleasures because their disproportion to our desire is constantly promised fulfilment by something else. (p. 128)

We thus live in a world eliciting new desires or deferring and providing more of the old ones. On this count, for instance, inebriation is viewed rather as an inability to handle alcohol than a pleasurable state; an orgasm is interpreted as the sexual inability to reach multiple climaxes during one sexual act (Miller 2003:129). Irrespective of one's views on the variety of alcoholic or sexual habits, the distinct question remains on how such a deferment strategy applies to matters of greater ultimate concern, religion.

Tradition does not provide us with one clear answer on this. One strain of Christian tradition portrays desire as characterised by both fulfilment and deferment, identity 
and discontinuity (Miller 2003:129-130). The Old Testament collection of Song of Songs can serve as the most eloquent example of unfulfilled desire, as the female lover tormented by her desire in certain instances searches in vain for her lover. Gregory of Nyssa took this, the female lover's loss, as an example of desire for the inexhaustible Divine, which cannot be fathomed either by reason or experience. The spiritual life should thus be seen as a progressive increase in desire: 'Never to reach satiety of desiring is truly to see God' (McGinn 1995:141). As a seeming opposite, one cannot ignore Augustine of Hippo who perceived restlessness as discomfort, displaying in this way his quietistic tastes, which can undoubtedly be put into connection with his personal biography, marked as it was by a succession of desperate searches for fulfilment. Miller (2003) points out in this respect just how easily religious experience may be harnessed into the service of such a deferment-oriented consumption dynamic:

The ever more intoxicated pursuit of an unattainable object, where fleeting, fragmentary experiences of union and fulfilment must always be left behind, can be transposed easily into the key of consumer seduction. If the side-tracking of the mystical ascent threatened to co-opt the desire for God into the service of consuming things, this form of mystical desire is most likely to reinforce consumerist religious habits: for example the earnest quest of the seeker, moving from one tradition, vision, and practice to another in an endless and stunted attempt to encounter God ... the similarity of form between the desire for God and consumer desire provides the danger of a subtle side-tracking that threatens the transcendence of God - or more properly - our sense of it. When the desire for God is assimilated to the workings of consumer desire, its disruptions and subversions, its demand for something more than the status quo is harnessed into service of a system that provides only more of the same. Through misdirection, advertising exploits any available desire in order to hawk merchandise. All of these other rich desires are channelled into one action which can never fulfil them. Seduction uses the surplus of dissatisfaction as a spur to encourage only more consumption ... The similarity between consumer desire and traditions that emphasize the endlessness of spiritual desire suggest a different problem - the shunting of this profound restlessness into a shallow form of seekerism. (p. 130)

Miller here draws quite a daring analogy. Consumerism defines the self as its capacity for experiences. There is always a promise of more excitable experiences or, at least, of more of the same. Can we get involved in an endless pursuit of fragmentary and fractured religious and spiritual experiences, without the prospect of satiation, in the same way that we give ourselves to the deferred enjoyment of other things? Can religious and spiritual experiences become objects of enchantment and relish in themselves, and is it legitimate to seek them for their own sake? In Miller's opinion, evidently, such an attitude may compromise our sense of the object these kinds of experiences are supposed to lead us to: the transcendent God.

It is undoubtedly this promise of never-ending spiritual experiencing that 'outsources' the pews of traditional Protestant churches and populates the more forgiving seats of mega-churches; the latter seem to be well-equipped to commodify spirituality and to cater to consumerist religious habits. In their work God is like a drug: explaining interaction ritual chains in American megachurches, Wellman, Corcoran and Stockly-Meyerdink (2014:650-672) describe the strategies used by mega-churches to energise their congregants with powerful emotional experiences of collective effervescence. These churches service a de-liturgised 'come-as-you-are' atmosphere, with rock music and a multisensory mixture of visuals and other elements to stimulate the senses of worshippers, strengthened by small group gatherings as well as black-and-white messages of the charismatic pastor. In the South African scene, this plays out in parallel, although differently contextualised ways (cf. e.g. Lombaard 2010). In spite of the clear marketing character of mega-churches' strategies, the overall judgement by Wellman et al. seems rather well disposed to the upbeat and uplifting spirituality. The search for ultimate concern by multitudes has been transformed into a 'drug'; yet, this may also be considered a 'good drug', because along with the high load of experiential stimulation, mega-churches also lay emphasis on imparting to the worshippers basic ethical standards, encouraging them to act as decent persons, to care for their families and to treat their fellow human beings with gentleness, understanding and forgiveness. Nor can one deny these churches credit for suffusing worshippers with a positive psychology: your life can be better and you can be happy.

From a pragmatic point of view, one may wonder about problematising the coupling of consumerist mentality with religious experience. To be sure, seeing salutary effects in having religious and spiritual experiences, Wildman extends this link by calling for the joining of spirituality and technology in the foreseeable future. In recent decades, religious and spiritual experiences have been the object of intensive scientific research: neurophysiology, neurology of social behaviour and neuropharmacology. Wildman thus conjures up a vivid imagery of the future use of psychosocial techniques, boosted by sophisticated technologies that customise sensory experiences to individual backgrounds and brains. For instance, although loud noises may be painful to some people and rhythmic movements and flashing lights do not work well with everyone, these techniques can still release positive and edifying feelings within the majority of people. Rhythmic music, a public address and visual effects may be regarded as instrumental in customising the social environment for cultivating religious and spiritual experiences that could bear strongly individualised consumerist characteristics (Wildman 2011:115):

Imagine a socially and emotionally intense religious gathering fifty years from now - something like Billy Graham Crusade or an evening with the Dalai Lama, but with a twist. The advertising describes the event as a customized religious experience in a diverse group of loving fellow believers - more realistic than holodeck theaters and more meaningful than coarse forms of human togetherness such as live sportive events and music concerts. Upon entering each person signs an informed consent document and is quickly analyzed using a microscopic drop of blood and a brain scan ... These noninvasive and painless 
procedures happen in mere seconds, and the analysis allows a program to seek optimal sensory parameters and physical location within the auditorium. The guest then moves to an assigned hi-tech seat that is automatically programmed with customized operating instructions. The location of the seat and its unobtrusive sensory equipment adapt the experience of the event to the individual's specific physiological profile. The result is a profoundly customized individually enhanced social experience ... (p. 233)

The above somewhat futuristic description of a religious or spiritual gathering can conform to some current tastes in which spirituality is supposed to operate solely as a therapeutic means. Such a form of spirituality will be marked by a lack of explicit reference to transcendence or even shared communal values, in which human existence is determined by an intensely private sense of well-being (Miller 2003:85). The feeling of personal well-being and psychological security may take precedence even over one's interest in salvation or social justice, or put differently, one's hunger for salvation and the coming of the Kingdom of God may find its temporary satisfaction in a strongly emotionally-laden or even ecstatic experience. Miller (2003:86-87) argues precisely this, that the 'boomer generation' favours experience over beliefs and generally stresses personal fulfilment. This tendency seems to cherish the reconfiguration of spirituality into a highly individualistic, psychologised and therapeutic enterprise - an inclination that can be found amongst evangelicals as well as New Age adherents.

However, in closing here, it should also be noted that the recurrent consumption of the same may have a wearingdown effect, and some people may eventually want to embrace or reunite with moderate, more conservative forms of worship that draw on centuries-long ecclesiastic and doctrinal traditions. This had, for instance, been the case with the well-known American publicist William Lobdell, who gives an account of his spiritual journey in his autobiography Losing My Religion: How I Lost My Faith Reporting on Religion in America - And Found Unexpected Peace (2009). In this book, Lobdell shows much of the contemporary 'seekers mentality', fuelled by a narcissistic pursuit of personal well-being. Lobdell experienced a sweeping born-again experience in a mega-church community, yet after spending several years there he started to find the environment disappointing, and its strategies - however exciting they might have been at first - tedious, shallow and not least, though paradoxically, impersonal, despite their being tailored to individual needs (Lobdell 2009):

I felt a growing muscularity to my Christianity. I was learning more and more about the Bible. I wanted to plunge deeper into belief, history and custom. I didn't need as much self-help as I had earlier. My life had long ago gotten out of intensive care and had stabilized. I started to feel claustrophobic at Mariners church. The seeker-friendly services - which had drawn me so effortlessly back to Christianity - now seemed simplistic. I wanted to strip away the happy songs, the upbeat, black and white messages and the cappuccino machines. I wanted something more authentic, more raw, even. I was grateful of my time at Mariners, but I felt I had graduated. We stopped going as a family one day and slipped away. Nobody noticed. That was the blessing and curse of belonging to a megachurch. No one knows you've arrived and no one knows when you've gone. (p. 54)

\section{The experiential-expressive model of religion in current theological thought}

Liberal theology was for a long time considered the only stronghold of the experiential-expressive model of religion. This is no longer true - nor has it been true for already three or four decades at least. The process of reducing the richness of spiritual life to experience has struck strong roots also in traditional evangelical environments. The typical doctrinal character of evangelical piety has in mainstream evangelicalism been exchanged for private experience. David Wells aired his grievances over this tendency in No Place for Truth: Or Whatever Happened to Evangelical Theology? (1993) some 20 years ago. It seems that not much has changed since then. Even those evangelical theologians who denounce the experientialexpressive model of religion are eventually caught redhanded, as their own theologies seem after all to lean on that model to various extents. A prominent example of these theologians is Allister McGrath, a prolific apologetic, as for instance the author of the impressive three volumes of Scientific Theology (McGrath 2001; 2002; 2003).

McGrath's theology is known for its extensive engagement in fostering dialogue between theology and natural science for the sake of tuning the workings of theology methodologically in to those of natural sciences. Epistemologically, McGrath aligned his position with critical realists such as Roy Bhaskar, levelling a sharp criticism against non-realist epistemologies, especially that of Richard Rorty (McGrath 2002:5-10). McGrath is convinced that science can play a supportive and illuminative role in contemporary theology, offering similar tools to those provided by Platonism to patristic theology and by Aristotelianism to medieval theology (McGrath 2001:17-20). The point of departure of McGrath's thought is the concept of nature. In his opinion, nature is a socially constructed concept, inevitable for a solid ontological grounding (McGrath 2001:82-132). There must be an ontological premise that grounds the concept of nature, and McGrath arrives at the conclusion that the Christian doctrine of creation can best fit that role. Our being should be ontologically thrown onto this foundation. The Old Testament theology of creation ought furthermore to be interpreted along the New Testament Christological and Trinitarian views of creation (McGrath 2001:158-159). Theology and natural sciences can hence coexist peacefully and cooperate, because the doctrine of creation assumes the existence of a fundamental correspondence between divine rationality, represented by the second person of the Holy Trinity, human rationality and the intrinsic structures of the created order. This correspondence not only provides an ontological foundation but, more importantly, also grounds McGrath's critical realism. From this perspective, our engagement with nature from both scientific and theological perspective takes on the contours of objectivity. 
The above premise has also enabled McGrath to take up a positive approach to pre-enlightenment natural theology, understood as 'from the standpoint of faith ... the consonance between that faith and the structures of the world' (McGrath 2001:266-267). Natural theology opens up the possibility for forging meta-traditional points of contact between different belief systems. In this way, Christian natural theology offers a coherent organising logic that accounts not only for its own existence but also for that of its rivals (McGrath 2002:78).

McGrath does not appear to be an explicit accomplice in fostering the experiential-expressive model of religion, and in his earlier writings he pays a certain respect to Lindbeck's cultural-linguistic model. In what almost sounds like Barthianism, McGrath bases the workings of theology solely on the bedrock of revelation. In doing that, he however does not diminish the value of religious experience. What we are offered is quite a balanced picture. While referring to the emotionalism of Martin Luther, McGrath argues that theology should address the experiential perspective of faith; however, faith must never be subjected to the dictates of the experiential (McGrath 1993). ${ }^{4}$ McGrath criticises Lindbeck in the later stages of his work, while covertly taking up some aspects of the liberal theological agenda that sometimes makes it to the surface of his writings, as in a passage in which McGrath expresses his indebtedness to Schleiermacher's understanding of doctrine as the expression of the experience of a God who is beyond language (McGrath 1997):

To caricature Christian doctrine, then as mere word-play or as an attempt to reduce the mystery of God to propositions is to fail to appreciate the manner in which words serve us. In order for my experience to be expressed, communicated to or aroused in another, it demands statement in cognitive forms. That these cognitive forms fail to capture such an experience in its totality is self-evident, and hardly a matter for rhetorical exaggeration: it is one of the inevitable consequences of living in history and being obliged to communicate in historical forms. Schleiermacher recognized that doctrine expressed an experience constituted by the language of the Christian community, thus pointing to the delicate interplay of cognitive and experiential elements in doctrinal formulations. (p. 70)

The upshot of the above quote, perhaps not quite clear at first glance, is that doctrinal statements can be reduced to a representational role and as such cannot raise a claim to

4.In an article entitled 'Theology and experience: Reflections on cognitive and experiential approaches to theology', McGrath (1993) states: 'Lindbeck points out, "religious experience: is a hopelessly vague idea. "It is difficult or impossible to specify be con "thenality becomes logically and, and yet unless this is done, the assertion of commonality are diverse symbolizations of one and the same core expeience of the Ultimate" is ultimately an unverifiable hypothesis, not least on account of the difficulty of locating and describing the 'core experience' concerned. As Lindbeck rightly points out, this would appear to suggest that there is "at least the logical possibility that a Buddhis and a Christian might have basically the same faith, although expressed differently" (p. 67). In the conclusion McGrath summarises: 'In this article, we have explored some of the ways in which theology and experience relate to each other. We have argued that there is no rightful place in Christian theology for any approach that is purely cognitive or purely experiential. Experience and understanding are like two sides of the same coin, which mutually reinforce and enhance one another. The liberal appeal to pure uninterpreted global experience is widely regarded as discredited, partly on account of the considerations noted by George Lindbeck and others [W] must insist that experience is to be addressed, interpreted and others [W] transformed in the light of the gospel proclamation of redemption through Christ, as this is made known to us through scripture. By thus anchoring theology in the bedrock of divine revelation, while linking it up to the world of human experience, we may ensure that Christian theology remains both authentic and relevant in the years that lie ahead. Theology can address experience, without becoming reduced to the level of a mere reiteration of what we experience and observe' (pp. 73-74). literal validity. Providing a framework for the Christian experience of the non-reducible mystery of God, doctrinal statements thus describe something that cannot be exhausted in words.

Eventually, McGrath subscribes to the experientially oriented liberal agenda even in hermeneutical issues, rejecting the explicit traditional evangelical identification of Scripture with the Word of God. The biblical texts per se cannot be identified directly with the revelation of God who dwells behind the confines of Scriptures. In the end, the task of the Scriptural text is to mediate the experienced redemption in Jesus Christ (McGrath 1999):

For evangelicals there is something real that lies beyond the text of Scripture which is nonetheless rendered and mediated by that text: the Christian experience of being redeemed in Christ. The emphasis on intratextuality tends to obscure the centrality of the person of Jesus Christ in Christian faith (and did so before the texts of the New Testament were written down). (p. 156)

The experiential-expressive model of religion comes to the fore most strongly in McGrath's book on natural theology, The Open Secret: A New Vision for Natural Theology (2008). In this work, McGrath makes an appeal to a universal human experience of the transcendence. By virtue of humankind's creation in the image of God that has been corrupted by sin, all persons have a sense that something has been lost. This sense of loss is a universal human experience of religious import, pushing humanity to search for transcendence. A Christian natural theology represents the theological counterpoint to that general quest (McGrath 2008:12-18). McGrath then specifies various kinds of experience that form people's conviction that there is 'something out there'. Some of these are religious experiences by their very nature and some not. Along numinous experiences that correspond to Rudolf Otto's awareness of a mysterium tremendum, ${ }^{5} \mathrm{McGrath}$ also enumerates mystical or epiphanic experiences, the latter being unique moments disclosing something of immense significance within the everyday ordinariness. 'All of these experiences, however, can be interpreted or related to a transcendent reality as sensations in which the mundane has given way to something beyond it: a kind of Wordworthian 'spots of time' charged with profound feelings and imaginative strength' (McGrath 2008:29-32). McGrath illustrates his stance with three recent examples of the human awareness of the transcendent: the moral philosopher Iris Murdoch, the critical realist philosopher Roy Bhaskar with his intimations of meta-reality, and finally - to the reader's surprise - also one of the fathers of American pragmatism, the atheist John Dewey (McGrath 2008:41-58). McGrath's selection nevertheless remains conspicuously confined to personalities whose worldviews and language have been grounded to various degrees in the Western and, even closer, the Christian intellectual fabric. One can wonder whether McGrath's natural theology can effectively account also for

5 . As pointed out in lombard (2015):4 Otto is associated almost by reflex with the expression mysterium tremendum et fascinans. However, he never uses this exact expression mysterium tremendum et fascinans. However, he never uses this exact formulation in 1917:98,112,126 and 179, and the formulation never comes as close formulation in 1917:98, 112, 126 
non-Christian and non-Western fabrics. Can the notion of transcendence and its experiential appropriation in consonance with Christian natural theology be reliably planted, for example, into the fabric of Buddhism, the core teachings of which seem to be occupied with cessation of suffering and of one's own self - and therefore lies beyond the dichotomy of transcendence and immanence? Eventually, is not McGrath's conception, despite his swearing off of presumptuous universalistic tendencies, still somewhat overconfident of the ability of Christian natural theology to account for non-Christian faiths?

One can wonder too whether McGrath's experiential appeal would optimally work even in other theistic contexts, such as Judaism. During his lifetime, Schleiermacher addressed also the issue of Judaism, which he believed, akin to his Protestant contemporaries, to be a defunct religion based on worn-out doctrines and obsolete practice (cf. Newman 1993:455-484). He called on his Jewish friends to embrace his romanticised form of Protestantism emphasising personal experience. As Heinze (2004:53) points out, some Jews of that period indeed 'delighted ... in the inward search that the German Romanticism prescribed' and regarded the attempt 'to get into sublime touch with one's soul ... as a basically Christian experience'. The religion of the heart, promising the intuitive union with Christ, nevertheless posed a serious threat to Jewish identity in the wake of Romanticism. One of the leading figures of the Jewish Reform Movement, Abraham Geiger, gravitated towards Schleiermacher's theology too, and his understanding of faith as an individual feeling provided one of the bases of Geiger's reform. Yet, as bluntly put by Eliezer Schweid (2011:95-97): 'Geiger was compelled to dance on the edge between the advantage of attaching himself to the reforming vitality of Protestant spirituality and the urge to protect the separate identity of Judaism. Geiger was not truly well disposed to Romanticism'. He accepted only its individualism, realising that individual emotionality started to play a crucial role amongst the youth of his generation. Yet, the new image of Judaism attuned to the needs of an individual assumed on the whole a moral rather than an experience-oriented character. Judaism reinforced its position vis-à-vis Christianity by bringing to the fore the moral superiority of Judaism as encoded in the Mosaic tradition. Hence, the American Reform rabbi Felix Adler founded the Society for Ethical Culture in 1876, with a view of spreading a strong moral philosophy amongst agnostic or atheist Jews (Heinze 2004:58).

Even within contemporary Judaism, one can find representatives of the experiential-expressive model of religion. For example, Martin Buber's I and Thou (1958 [1923]) fosters a kind of generic religious experience that does not require any particular communal identity. In contrast to Buber, his friend Franz Rosenzweig argues that religious content can be communicated only through particular communal forms. Had he been acquainted with Lindbeck's terminology, Rosenzweig too would have frowned on the experiential-expressive model of religion, because in his opinion, the redemptive qualities of Jewish monotheism cannot be exhausted by referring to some underlying generic generality, but only by way of its particularity. It was apparently the motive of Jewish particularity that incited him to establish the Lehrhaus in Frankfurt, with a view to providing individual Jews with skills such as knowledge of Hebrew and of Jewish traditional texts that would enable them to reunite with Jewish communal life (Batnitzky 2000:209-210).

\section{Is there still something to be learnt from Lindbeck?}

Reviewing the argumentation above, it becomes evident that experientially oriented forms of spirituality as a kind of consumable capable of bringing the religious practitioner closer to the transcendent, more effectively than any other source, still persists in the church pews, and to some degree even exert an impact on the agenda of theological seminaries and faculties. Some churches seem to be almost paralysed by it, as is the case of the home church group of the first author of this contribution, which despondently struggles to retain something from its Lutheranism, tinged by a moderate form of pietism, and not to succumb to the assertive rhetoric of a lay evangelical movement that revolves around the bornagain experience, operating within the framework of that church. ${ }^{6}$

In his exposition of the cultural-linguistic alternative to the experiential-expressive model of religion, Lindbeck views faith as a sort of linguistic framework that shapes the entirety of life. On this count, religion can be featured as a 'language idiom' that enables religious communities to describe realities, formulate their beliefs and experience religious feelings and sentiments. In contrast to the experiential-expressive model, it is that religious idiom as a cultural phenomenon that shapes the subjectivities of individual practitioners, and not the other way around (cf. Wildman 2011:11-13). Expressive and communicative symbols, irrespective of whether they are linguistic or non-linguistic, represent a precondition as a culturally formed a priori for the possibility of experience (Lindbeck 1984:32-33).

In presenting religion as a communal and language-based phenomenon, Lindbeck undoubtedly shows a particular indebtedness to Ludwig Wittgenstein's Philosophical Investigations (1953), but his views are generally in line with the linguistic turn in philosophy, especially neo-pragmatism, which has now fallen out of favour because of the notion of experience, attempting to replace it by discourse theory or linguistic behaviourism. Challenges to experience have arisen also in the philosophy of science. In The Structure of Scientific Revolutions (1962), Thomas Kuhn argues that scientists not only adopt new instruments and look in new places during scientific revolutions, but also start to see new and different things when using unfamiliar instruments while looking in places they had looked before (Kuhn 1962:111). The fundamental claim made by Kuhn regarding scientific progress was that observation is strongly 6.The Silesian Evangelical Church of the Augsburg Confession (SECAC), the Iargest Lutheran church in the Czech Republic. 
theory-dependent, and the very process of seeing something is dependent on education. We see by means of different paradigms. For example, we may doubt whether the Aristotelians and Galileo saw the same thing when observing a rock swinging on the end of a stick: Galileo saw a pendulum, an example of constrained fall; the Aristotelians apparently did not, because the pendulum is an object that acquired its particular meaning within the scientific context that came into being only after Aristotelianism (Kuhn 1962:118-119).

As mentioned above, the linguistic turn in philosophy therefore intends to replace experience with discourse. Experience is, in this line of thinking, always propositional and therefore linguistic. The preference for discourse over experience is in particular palpable in Richard Rorty's thought. The notion of experience can at most be used as a reference to non-inferential judgements caused in the physiological condition of sense organs (Rorty 1998:123). Leaning on this linguistic behaviourism, Rorty speaks of human 'programming', which relates to the acquisition of discursive practices that play an essential role in our initiation into a language community, in which we then learn the practices of reason-giving and conversation. Rorty draws attention to the discrepancy between the sensory 'input' and the conversational 'output' as the response to sensory stimulation. The stimuli input as the process of undergoing physical changes, prompted by the environment, is rather 'thin' compared with the extensive output, resulting in a 'thick' web of conversional practices. To report an experience means to respond to being in a certain mental state with whatsoever sentences one's linguistic community 'programmed' one to use in that situation (Janack 2012:45-46).

Lindbeck's definition of religion as a communal and language-based phenomenon corresponds to Rorty's integration of religion into what he calls 'cultural politics'. Cultural politics, as Rorty says, ought not to be reduced to policing hate speech. It should rather address larger social issues, such as terminating the use of concepts like 'race' or 'caste' and the division of the human community by genealogical descent (Rorty 2007:3-5). Referring to his colleague Robert Brandom, Rorty argues that cultural politics takes precedence over ontology, blocking out effectively appeals to such notions like reality, truth or experience. The precedence of the social over the ontological has also its say in religious matters, and Rorty explicitly refers to religious experience. It is the community that enables our statements. Even our reports of physical objects have to live up to the expectations of the community we share. Thus, our religious reports are part of an overall, concerted, cultural-political initiative too (Rorty 2007:9-12). A person's reporting of her personal experience of God as a female to a Christian community whose speech of God is strongly embedded in masculine categories will certainly result in failing to meet that community's reflexive expectations. Using Lindbeck's terminology, such a report would be at odds not only with the community's specific dogmas, but also generally with its 'idiom' as a medium that shapes the entirety of communal life and thought. ${ }^{7}$

It has also to be noted that Lindbeck's critical attitude to the experiential-expressive model of religion has been in addition to the linguistic turn in philosophy nurtured by another source, namely the theology of Karl Barth although these sources, except perhaps for some loose connection to neo-Kantianism, have no common ground. In coining his concept of God as the 'Wholly Other', Barth refused the idea of God's being 'somewhere out there' for us in experience. This can be shown in the controversy between Karl Barth and Georg Wobbermin, the German translator of William James's The Varieties of Religious Experience. In his Richtlinien evangelischer Theologie zur Überwindung des gegenwärtigen Krisis (1929), Wobbermin criticised Barth for his apparently flawed understanding of the relationship between faith and experience. In Wobbermin's view, Barth significantly downplayed the subjective side of faith, effectively excluding this personal experience (McCormack \& Anderson 2011:106-107).

Barth defended himself in his Church Dogmatics by arguing that the Word of God is not something standing freely at the believer's disposal. Barth refuted the assumption of 'Christian Cartesianism', according to which the reality of the Word of God cannot be anthropologised and thereby reduced to some general human capacity, which includes also the capacity for religious experience. Personal religious experience is exposed by Barth as the threat of believers turning inside themselves and becoming self-focused. As the worst case, the objective side of faith, the Word of God, can in personal experience be degraded to a predicate of human existence or to the content of consciousness (Barth 1975:214). This, nevertheless, does not mean that Barth banned experience from the precincts of his theology altogether. He concludes the section of his Church Dogmatics' first volume dedicated to this problem by stating that religious experience cannot be the ground of faith, but 'in faith men have real experience of the Word of God' (Barth 1975:238). Religious experience can thus be viewed rather as a confession that rules out the possibility of possessing the Word of God, and Barth couches this observation in a sort of paradoxical statement: 'by taking place as an experience this experience ceases to be an experience' (Barth 1975:209).

As pointed out by McCormac and Anderson (2011:110-111), besides transcendentalism, Barth shared with neo-Kantians a dislike for psychologism, which led him to the conviction that no serious theology can be built from patches of experience and that church doctrines cannot be violated by transforming them into vivid experiences of sin and grace (McCormac \& Anderson: 110-111).

7.Noteworthy is also the contribution of the non-conformist Anglican theologian Don Cupitt for his unrelenting criticism of religious experience, and whose religious thought has accommodated within its precincts a great deal of Wittgenstein's thought has accommodated within its precincts a great deal of Wittgenstein's
philosophy of language as well as Rorty's neo-pragmatism. See his Mysticism after philosophy of language as well as Rorty's neo-pragmatism. See his Mysticism after
Modernity (1997) or his Turn of Phrase: Radical Theology from A to Z (2011:96-97). 
The Canadian theologian James Smith (2014:156-157) recently attempted to evaluate the actuality of Lindbeck's basic theses. He particularly points to Lindbeck's conviction of the experiential-expressive model being the dominant feature of religion in modernity, and his prediction that with the advance of a post-Christian age this model would become an even more entrenched and desired commodity in church pews and theological reflection. This will put both ministers and theologians under a growing strain to provide their parishioners and students with a sense of transcendence through highly psychologised kinds of spirituality (Lindbeck 1984):

As we move into a culturally (even if not statistically) postChristian period, however, increasing numbers of people regard all religions as possible sources of symbols to be used eclectically in articulating, clarifying, and organizing the experiences of the inner self. Religions are seen as multiple suppliers of different forms of a single commodity needed for transcendent selfexpression and self-realization. Theologians, ministers, and perhaps above all teachers of religion in colleges and universities whose job is to meet demand are under great pressure in these circumstances to emphasize the experiential-expressive aspects of religion. It is thus that they can most easily market it. (p. 22)

What weighed heavily on Lindbeck's heart was the growing interiorised and de-practiced character of Christian spirituality. The churches have become purveyors of an individual quest for symbols of transcendence that communities can socialise their members into, creating coherent and comprehensive religious outlooks and forms of life (Lindbeck 1984:126). The cultural-linguistic model has proven to be more holistic in its agenda. In this case, being a religious person is bound up with the appropriation not of one, but of a range of skills - thinking, acting and feeling - in conformity with one's own religious tradition and its inner structure (Lindbeck 1984:35). In this way, religion turns into a sort of initiation rather than a source of information or experience, a matter of 'know how' before it can become a matter of 'know that' or 'experience of' (Smith 2014:159).

The health and vitality of Christian spirituality is therefore closely related to its communal framework, in which a believer does not only construct himself or herself as a monad connected with co-believers through a thin link of common desire for personal salvation, by gaining some religious experiences or accepting certain doctrinal propositions. Rather, faith is entirely embedded in the communal life marked by the variety of its spiritual expressions, and its everyday matters are handled in the spirit of the ancient ecclesiastical slogan: 'unity in necessary things, liberty in doubtful things, charity in all things'. We are saddened by the prospect that Lindbeck's theological contribution may even face the possibility of never being fully appreciated, because the current theological discourse has entered a new stage in which critical realism seems to be taking the upper hand, sending much of the late 20th century post-modern, culturally relativist, social constructivist and pragmatist strains in theological thought into gradual oblivion, with Lindbeck himself left behind, ridiculed for failing to 'offer a satisfactory account of how doctrines are grounded in any reality' (McGrath 2002:53-54).

In making a case for Lindbeck's linguistic-cultural model of religion, Smith (2014:169) addressed the issue of the relation between realism and community-based relativism. Even though a statement like 'Jesus Christ is Lord' may be relative to a community of practice, this does not imply that the Gospel remains a private secret reserved for the members of the group. Pragmatism does not result in a sort of postmodern 'gnosticism', the secrets of which are conveyed only to the initiated (Smith 2014:169). If McGrath grounds his critical realist theology in the doctrine of creation, so does Smith. However, the latter's reference to our creatureliness does not invoke the epistemological certainty based on the fundamental correspondence between divine rationality, human reason and the intrinsic structures of the created order. It rather places our being in the genuine contingency that characterises creatures. Pragmatism does not necessarily give up on witness and apologetics, but retools it in accordance with our creatureliness. Pragmatists' appreciation of the contingency does not preclude the possibility of making universal assertions. It just assumes that it is not possible to make it from an objective and absolute standpoint. Religious communities will always come out of their centre towards a more universal horizon that is tantamount to an environment shared with other communities, prompting them to engage in a constructive dialogue and to exchange of perspectives. Yet, the intelligibility of such an environment does not have a natural character. It is a social accomplishment relying not on theory or independently formulated criteria, but on skill and good performance. While engaged in apologetics, Christianity can only call upon its reasonable plausibility possibly to persuade a non-Christian to try the way of life in the body of Christ (Smith 2014:174-175).

Smith also pauses to discuss the force of Lindbeck's point in his criticism of the experiential-expressive model of religion, and in particular in relation to its absorption by conservative evangelicalism, the rhetoric of which gravitates toward translating the Gospel into an experience that addresses 'the proverbial God-shaped hole that remains in the middle of our consumerist hearts' (Smith 2014:172). What is marketed in this case is, according to Smith, a 'therapeutic god' that exists only in order to meet our personal needs and fill our lives with greater contentment. In this respect, Smith's poignant analysis of that subject is on a par with the views expressed above, addressing the disconcerting problem of the ongoing unhealthy inflation and hypertrophy of private religious experience for which a remedy has not yet been found.

Perhaps we are weeping over this state of affairs in vain, and instead we should swim with the tide, humming under our breath musician Bobby McFerrin's famous song, 'Don't worry, be happy'. We cannot ignore the social factors that already operate on the global level, including urbanisation 
and technology, which transcend boundaries and places, languages and customs, creating a world which 'belongs to everyone because it belongs to no one in particular' (Wells 1993:56). These aspects have an immense impact on current trends in popular spirituality. With the omnipresent individualisation, we are faced with a constellation of factors that do not seem to be well inclined towards denominationalism or a steady, serious intellectual engagement with an own theological tradition. Psychologisation of religion had undoubtedly contributed to the abandonment of the pursuit of the cognitive aspect of faith, which on its part suffers from the retreat into spiritual privacy in which doctrinal propositions have often been reduced to such clichés as 'Jesus loves me' or 'Christ has died for me'. This mood has taken grip on clergy too, with some having adopted a pronounced anti-theological stance, happily slipping in this way into the roles of psychological counsellors and managers rather than that of theologically well-educated ministers. The psychological counsellor controls the inner world; the manager the outer. Theological seminaries conveniently continue to churn out both of them. In whichever ways this may bother us, while continuing to nurture philosophically justified distrust towards experience, eventually we should probably in the spirit of pragmatism make our peace with 'therapeutic' religious practices, no longer seeing them as non-equals to the moderate traditional forms of worship and piety, accepting that many people can still find in them happiness and a measure of intimacy, spirituality, all the while calling for moral integrity and social commitment.

\section{Acknowledgements Competing interests}

The authors declare that they have no financial or personal relationships which may have inappropriately influenced them in writing this article.

\section{Authors' contributions}

D.B. and C.L. equally contributed to the research and writing of this article.

\section{References}

Alston, W.P., 1991, Perceiving God. The epistemology of religious experience, Cornell University Press, Ithaka.

Barth, K., 1975, Church dogmatics. Volume 1: The doctrine of the Word of God, T\&T Clark, Edinburg.

Batnitzky, L., 2000, Idolatry and representation. The philosophy of Franz Rosenzweig reconsidered, Princeton University Press, Princeton, NJ.

Buber, M., 1958 [1923], I and thou, T\&T Clark, Edinburgh.

Cupitt, D., 1997, Mysticism after modernity, Wiley, Hoboken, NJ.

Cuppit, D., 2011, Turns of phrase. Radical theology from A to Z, SCM Press, London. DeHart, P.J., 2006, The trial of the witness. The rise and decline of postliberal theology, Blackwell Publishing, Malden, MA.

Heinze, A.E., 2004, Jews and American soul: Human nature in the 20th century, Princeton University Press, Princeton, NJ.

James, W., 2002 [1902], The varieties of religious experience. A study in human nature, The Pennsylvania State University, Philadelphia, PA.

Janack, M., 2012, What we mean by experience, Stanford University Press, Stanford, CA.

Kourie, C., 2006, 'Postmodern spirituality in a secular society', in C.W. Du Toit \& C.P. Mayson (eds.), Secular spirituality as a contextual critique of religion, pp. 75-94, Research Institute for Theology and Religion, University of South Africa, Pretoria.
Kuhn, T.S., 1962, The structure of scientific revolutions, Chicago University Press, Chicago, IL.

Lindbeck, G.A., 1984, The nature of doctrine: Religion and theology in a postliberal age, The Westminster Press, Philadelphia, PA.

Lobdell, W., 2009, Losing my religion: How I lost my faith reporting on religion in America - And found unexpected peace, HarperCollins, New York.

Lombaard, C., 2010, 'Buchan brou',

- www.litnet.co.za/Article/buchan-brou

- http://teo.co.za/buchan-brou

- http://blogs.litnet.co.za/gerritbrand/2010/05/31/lombaard-skryf-buchan-brou

- http://uir.unisa.ac.za/bitstream/handle/10500/13819/Geredigeer\%20 ChristoLombaardBuchan\%20brou.pdf?sequence $=1$

Lombaard, C., 2015, 'Hol(e)y texts; hol(e)y lives: On the Psalms and spirituality. With particular attention to Thessalonia DePrince, Thomas Merton and Beat Weber Described, compared and evaluated', Scriptura 114, 1-13. https://doi.org/ 10.7833/114-0-1139

Manning, R.R., 2009, The Cambridge companion to Paul Tillich, Cambridge University Press, Cambridge.

McCormac, B.L. \& Anderson, C.B., 2011, Karl Barth and American evangelicalism, William B. Eerdman Publishing Company, Grand Rapids, MI.

McGinn, B., 1995, The presence of God: A history of western mysticism. Volume 1: The foundations of mysticism, Crossroad Publishing Company, New York.

McGinn, B., 2001, The mystical thought of Meister Eckhart, Crossroad Publishing Company, New York.

McGrath, A., 1993, 'Theology and experience: Reflections on cognitive and experiential approaches to theology', European Journal of Theology 2/1, 65-74.

McGrath, A., 1997, A study in the foundations of doctrinal criticism, Regent College Publishing, Vancouver.

McGrath, A., 1999, A passion for truth: The intellectual coherence of evangelicalism, Intervarsity Press, Downer's Grove, IL.

McGrath, A., 2001, A scientific theology. Volume 1: Nature, William B. Eerdmans Publishing Company, Grand Rapids, MI.

McGrath, A., 2002, A scientific theology. Volume 2: Reality, William B. Eerdman Publishing Company, Grand Rapids, MI.

McGrath, A., 2003, A scientific theology. Volume 3: Theory, William B. Eerdman Publishing Company, Grand Rapids, MI.

McGrath, A., 2008, The open secret: A new vision for natural theology, Blackwell, Malden, MA.

Miller, V.J., 2003, Consuming religion. Christian faith and practice in a consumer culture, Continuum, New York.

Moltman, J., 1992, The spirit of life, Fortress Press, Minneapolis, MN.

Newman, A., 1993, 'The death of Judaism in German Protestant thought from Luther to Hegel', Journal of the American Academy of Religion 61/3, 455-484. https:// doi.org/10.1093/jaarel/LXI.3.455

Otto, E., (Hrsg.), 2005a, Weber, Max: Die Wirtschaftsethik der Weltreligionen. Das Antike Judentum. Schriften und Reden 1911-1920 (Max Weber-Gesamtausgabe, Band I/21,1), Mohr Siebeck, Tübingen.

Otto, E., (Hrsg.), 2005b, Weber, Max: Die Wirtschaftsethik der Weltreligionen. Das Antike Judentum. Schriften und Reden 1911-1920 (Max Weber-Gesamtausgabe, Band I/21,1), Mohr Siebeck, Tübingen.

Otto, R., 1917, Das Heilige. Über das Irrationale in der Idee des Göttlichen und sein Verhältnis zum Rationalen, Trewendt \& Granier, Breslau.

Otto, R., 1923, The idea of the holy: An inquiry into the non-rational factor in the idea of the divine and its relation to the rational, 2nd edn., Oxford University Press, Oxford.

Proudfoot, W., 1985, Religious experience, University of California Press, Berkeley, CA. Rorty, R., 1998, Truth and progress, Cambridge University Press, Cambridge.

Rorty, R., 2004, 'Some inconsistencies in James' varieties', in W. Proudfoot (ed.), William James and a science of religions, pp. 86-97, Columbia University Press, New York.

Rorty, R., 2005, 'Anticlericalism and atheism', in S. Zabala (ed.), The future of religion, pp. 29-42, Columbia University Press, New York.

Rorty, R., 2007, Philosophy as cultural politics, Cambridge University Press, Cambridge.

Schweid, E., 2011. A History of Modern Jewish Philosophy, Vol. 1: The Period of Enlightenment, Brill: Leiden \& Boston.

Smith, J.K.A., 2014, Who is afraid of relativism? Community, contingency, and creaturehood, Baker Academic, Grand Rapids, MI.

Steinbock, A.J., 2007, Phenomenology of mysticism: The verticality of religious experience, Indiana University Press, Bloomington, IN.

Taves, A., 2009, Religious experience reconsidered. A building block approach to the study of religion and other special things, Princeton University Press, Princeton, NJ.

Tillich, P., 1974 [1912], Mysticism and consciousness of guilt in Schelling's philosophical development, Bucknell University Press, Lewisburg, PA.

Turner, D., 1995, The darkness of God. Negativity in Christian mysticism, Cambridge University Press, Cambridge. 
Twiss, S.B., 1992, Experience of the sacred: Readings in the phenomenology of religion, Brown University Press, Hannover.

Wellman, J.K., Corcoran, K.E. \& Stockly-Meyerdink, K., 2014, 'God is like a drug: Explaining interaction ritual chains in American megachurches', Sociological Forum 29/3, 650-672. https://doi.org/10.1111/socf.12108

Wells, D.F., 1993, No place for truth. Or whatever happened to evangelical theology, William B. Eerdmans Publishing Company, Grand Rapids, MI.
Wildman, W.J., 2011, Religious and spiritual experiences, Cambridge University Press, Cambridge.

Wittgenstein, L., 1953, Philosophical investigations, Blackwell Publishers, Oxford.

Wobbermin, G., 1929, Richtlinien evangelischer Theologie zur Überwindung der gegenwärtigen Krisis (Studien zur Systematischen Theologie, Heft 3), Vandenhoeck \& Ruprecht, Göttingen. 